\title{
Working while studying - some legal and political questions affecting the right to higher education in Estonia
}

\section{Kristi Joamets, Maria Claudia Solarte Vasquez}

PhD Department of Law, School of Business and Governance, Tallinn University of Technology, Estonia

\begin{abstract}
This paper explores some of the social dimensions affecting higher education policies in Estonia, and in respect to the European Union (EU) institutional framework and priorities, and looking at higher education as a fundamental human right. From this perspective, the aim is to establish that understanding underlying phenomena becomes key to respond strategically, raise awareness and improve the development of academic policies at the national and institutional levels. The combination of work and studies is one of the most critical dimensions to factor into this assessment but it has been neglected in the practice. Lecturers and other faculty members intervene, developing independent academic policies and initiatives in the absence of a preconcerted strategy, expertise, mandate and/or capabilities. Instead, universities should prepare for unorthodox engagements adapting to the students in need, and train their faculties to facilitate a shift towards less traditional learning environments. Responsive adjustments to the current social developments can be interpreted to be the proper way or the state to perform its duties and to better guarantee the exercise of the human right to education.
\end{abstract}

Keywords: working while studying; right to education; education policy;responsive policy; Estonian higher education policy. 


\section{Introduction}

The social dimensions of the higher education policies in the European Union (EU) have become priority concerns for all member states. 1 Better student life conditions are expected to have a positive impact on the region's research and innovation capacities and promote growth. The combination of work and studies gains relevance as one of the most critical dimensions, with serious implications on academic and labour market performance. Devlin et al (2008) said: "The working student is likely to be a reality for universities regardless of the level and availability of income support. /.../ The traditional idea of linear school, university, work progression, which still informs much policy and practice in high education, no longer holds true."

Broad changes in the structures of labour relations push the expansion of working while studying as well as the need to become competitive in the labour market obtaining field experience and training non-academic skills. The flexibilization of employment rules and policies in general, has allowed differentiated types of contracts and opportunities that did not exist in the past, such as work on demand, part-time and working from home. It would be useful if a matching flexibilization of academic rules and policies could follow.

Estonian policy makers should share these concerns as the percentage of students who work in the country increases steadily, raising to 32\% in 2016, when 53\% of the students who work did so during study periods (PRAXIS 2017, p. 53, 98). According to the EUROSTUDENT (2016-2018), this is common also in other member states where work is necessary to cover for the costs of higher education. The figures vary nonetheless; it is reported that in Central and Eastern Europe, students work more than 30 hours per week and in Western Europe up to 28, while in Denmark, Netherlands, Germany and Switzerland, they spend less than 20 hours working. In Estonia, students work because of financial reasons, mainly; 66\% cannot afford studying alone (PRAXIS 2017, p. 5-6). Similarly to the students from other EU countries, they cannot exclusively rely on parental and state support (see e.g. Kalenkoski et al 2008). Furthermore, working while studying has extended to the secondary school level where the students have the need to engage in paid jobs because some of them already have dependants or/and work to save for future study related expenditures.

While the right to education is indisputably a fundamental human right consigned in the Estonian Constitution, it was seen to include the right to higher or tertiary education when the European courts recognized it (Gilchrist, 2018). The extent to which the state is responsible for people's formal learning processes should also be clarified, given the incentives and promotion of lifelong learning in Europe (McCowan, 2012). For states to determine how to support students more responsively, a wider range of research and

\footnotetext{
${ }^{1}$ About the EU policy on education see: https://ec.europa.eu/education/policies/highereducation/inclusive-and-connected-higher-education_en
} 
discussions are warranted. This paper briefly introduces some of the dimensions that should be factored in the planning and formulation of responsive policies and legislative developments affecting higher education in Estonia, taking into consideration the need to generate institutional adaptability capacities in the sense indicated by Tomasevski (2006), and facilitate inclusiveness.

\section{High education as a human right and constitutional right}

Tomasevsky (2006) worked and reported governmental human rights obligations in education, structured into a so called '4-A scheme' -education must be available, accessible, acceptable and adaptable. She explained that the concept of adaptability was developed by courts when addressing the right to education of children with disabilities, but this paper argues that it is an institutional capacity applicable at all other levels by extensive interpretation. Governmental obligations in connection to human rights include proactive action and reaction in pursuit of goals and to achieve particular results, thus adapting becomes a core feature of the state's educational strategies as it would mean to put in place corrective actions when required. Tomasevsky's scheme endorses the inclusiveness defined as "concerned with identifying and overcoming all barriers for effective, continuous and quality participation of all in education” (Ramchand \& Dummugudem, 2014).

An inclusive right to education is established in art. 37 of the Estonian Constitution. Therefore, and recognizing the importance of the ongoing debate on whether higher education constitutes an objective responsibility of states or a privilege (McCowan, 2012), a broad interpretation of inclusiveness is assumed and core to the discussion proposed in this paper. Art. 26 of the Universal Declaration of Human Rights of 1948 (https://www.ohchr.org/EN/UDHR/Pages/UDHRIndex.aspx), established that "high education shall be equally accessible to all on the basis of merit“. The same principle is reflected in other international conventions, e.g. the United Nations International Covenant on Economic, Social and Cultural Rights (https://www.ohchr.org/en/professionalinterest/pages/cescr.aspx), the International Convention on the Elimination of all Forms of Discrimination against Women http://www.un.org/womenwatch/daw/cedaw/cedaw24/cedawcegy45.pdf), and the UNESCO Convention Against Discrimination in Education (http://portal.unesco.org/en/ev.phpURL_ID=12949\&URL_DO=DO_TOPIC\&URL_SECTION=201.html) (Gilchrist, 2018. pp. 645; 676). Furthermore, The Council of Europe declared that fair and equal opportunities of access to tertiary education should be available to all the capable and willing (Council of Europe 1998:2.1).

If the right to education should exclusively depend on will and merit, the students' financial status cannot impede study access without raising serious concerns. Most discussions focus 
on admission processes, but refrain to address subsequent challenges such as financial strain during the time of studies or the inability of the students to balance incompatible schedules and responsibilities deriving from the academic policies of universities and other higher education institutions. Even though it is not possible to guarantee certain outcomes in the exercise of the right to education, working while studying is an expanding phenomenon that affects the achievement of individual, collective, institutional, state and regional goals significantly (Communication, 2017). It can be said that when higher education institutions ignore the larger scope of student's constraints, they are violating constitutional rights and undermining the development of their "full dignity and potential” (Gilchrist, 2018, p. 647).

The Estonian EUROSTUDENT VI survey, revealed that while students graduate from high school at age 19-20, the average student at the tertiary level is 25-26 years of age, and a large proportion of them are 30 and older. $87 \%$ of these belong to the segment that are employed amounting two out of three students (PRAXIS, 2017). What is more, the education policy in place benefits people enrolling in the university right after secondary school, despite the demographic evidence showing that most of the student population are not recent highschool graduates and are much older. In the light of the data, the state should adjust the existing policies to meet the actual needs of the student population and to help it institutions to adapt. This should involve facilitating for people the balance between work and studies.

The country's higher education reform of 2013 sought to eliminate obstacles to access tertiary education. However, it does not refer to full-time day-studies students who also work. Similarly, the reform refers to scholarships, financial support and study loans, but fails to create or promote the conditions for students who need to work (see Kõrgharidusprogramm 2017-2020). In the absence of guidelines or explicit indications to interpret the state education policy as in support of the combination of work and studies, it is not possible for academic directors and manager level officials in universities, to justify and develop effective ones on their own; some strategies and decisions could contradict state policies and/or step over the boundaries of the institutional mandates. It is observable that university staff and faculty members consider that the primary and perhaps only occupation of students should be their study plan. Full dedication to the university activities is encouraged, expected and in times required to pass some courses. However, this view does not consider the limitations of the students or responds to the constraints of the institutions, such as the shrinking of the student population and the reduction of budgets that have forced the closure of distant learning programmes and other differentiated instruction schemes. Nowadays, full-time day-study groups are mixed with part-time groups, paying students with non-paying students, and people of all ages, backgrounds and expertise. It would be reasonable for universities, to ensure an acceptable student enrolment, to consider the proportion of students who have to work, and useful to adapt to the socioeconomic reality. This could be done by re-organising traditional academic strategies and adding flexibility rather than to forcing people to choose 
between exercising the fundamental right to education and/or making studying and working orthogonal to one another in practice (PRAXIS, 2017, p. 5-6).

\section{State support versus working}

To maintain a full-time status, a student must complete 30 ECT per semester, that is, 16 weeks, and means a learning average of 48 hours per week. Similarly, 48 hours is the maximum an employee can work weekly (the standard is 40 hours according to Estonian labour law), and this may be the situation for many students considering the demographic segmentation revealed in the aforementioned study. In average, a student who is older than 30 years, spends ca 70 hours per week combining work and studies: 16 hours for lectures, 16 hours for independent studies, and 38 hours for work. In addition, at least $72 \%$ of those already have children, which increases their responsibilities, and intensifies their workload significantly (PRAXIS, 2017).

At first glance, the support allowances for full-time day-studies in Estonia appear to be generous: First, most programmes in state universities are tuition-free; Second, study loans, basic allowances and need-based allowances are widely available, employees have the right to get study licences yearly, the libraries are excellent, and provide access to the main academic databases and all the resources required at no fee, and dormitories are affordable. However, at a closer look, these benefits hardly alleviate any of the personal or financial limitations experienced by the students, which according to the literature, is also the case in a number of other countries (Hortósy et al., 2018; Devlin et al., 2008; Evan et al., 2014).

Currently, to obtain a study loan of $2000 €$ per study year (166 €/month), that must be repaid right after graduation, an applicant should have at least two guarantors or be able to constitute a mortgage. The basic allowance that is supposed to cover study-related expenses comes from the university budget and is granted for only 10 months per year, depending on the students' performance. It is usually set at $100 €$ (higher profession-based scholarships in are allocated to specific curriculums). The allowance assigned on the basis of financial need ranges between 75-220 € per month, paid 10 months a year, and calculated according to the family income. Family include the parents of students up to 24 years of age, if not married, or when the parent or guardian of a child. Minor siblings and half-siblings are also family members. Up to $52 \%$ of the applying students get this allowance, but only $1 / 3$ of these get $220 €, 21 \%$ get $135 €$ and $44 \%$ get the minimum amount of $75 €$ (Valk, 2018, p. 18).

Linking the students' financial capacity to the family income until they are 24 years of age is a controversial provision, and feedbacked by the students as an unfair system (Valk, 2018, p. 5), because according to Estonian Family Law Act, the parents are obliged to maintain a child only until the age of 21 . On the one hand, parents do not have to support a child after turning 22 , but on the other hand, when applying to the need-based allowance, the income of the 
parents accrues the applicant's, diminishing the allowance that she/he may be otherwise entitled to. It could also be asked whether the law respects human rights consigned in the constitution and other international regulations, or follows the general principles of law. The majority of students in Estonia finish their bachelor studies at age 23, when they have technically lost the right for parental support. Even if some of the parents continue to help their children financially after that age, it cannot be assumed, thus this regulatory oversight should be addressed.

To summarize, the amount of money that a student can receive from the state, would consist of: a study loan - $166 €$ per month; a study allowance - $100 €$ for 10 months, depending on grades, and very sparingly granted; and an allowance based on need - 75-220 €, mostly set at the lowest (Valk, 2018, p. 5), for a total of 341€, that is less than a minimum legal salary (currently set at $540 €$ ). The average monthly study and living expenses, excluding accommodation, such as food, transport, clothes, medicines, equipment and supplies etc. by far exceeds this sum.

The insufficient availability of funds and lack of financial resources from the state have changed the students' attitude towards allowances (PRAXIS, 2017). They must cover for many of their basic needs on their own. Working while studying is the trend even among the students that receive support. More income does not only represent better living standards, but these students consider that working experience is an additional value and makes them more competitive as employees in the labour market. They learn time-management, communication and problem solving skills at work (Darolia, 2014, p. 47). Pemberton et al. (2013, p. 269), notes that those “'Employability skills' have become more important than just the degree”. The Estonian 2015 survey (Valk, 2018 p. 5) shows that for 8 in 10 students, getting an allowance had no impact in their decision to work at the time of studies. Other reasons should be researched more systematically to explain the in detail the student's motivations. For example, Hovdhaugen (2015, p. 633) found that in Norway student loans are more than enough to fully support students, but they still prefer to go to work. The data available in Estonia is inconclusive.

\section{Conclusion}

This paper showed that the combination of work and studies is one of the most critical and yet overlooked dimensions in education policies, with unaccounted implications on academic and labour market performance. Comments such as: "I was working the whole day and night, even though I had learned for the exam I was too tired, and could not concentrate or think clearly", and "I am too busy at work and could not study for the test" are becoming too common at all levels in Estonian universities. Absences are also on the increase, with students trying to comply with too many responsibilities at the time, and becoming unable to attend 
classes and participate in examinations, not to mention other academic activities. This should seriously impact the quality of teaching and the courses' management of lecturers, but remains largely under researched, as well as is the effect that studying may have on their work. At present, the faculty members are on their own to decide how to adjust their courses, and on a case by case basis, without institutional backup or clear guidance to legitimate these processes. At the administrative levels of the universities and related state entities the awareness of the need for updates and unity is lower. It seems necessary to introduce correctives, formulate new and effectively inclusive 'flexible learning schemes' or proposals that could adapt to reality responsively, and train employees to work with these students or search for faculty members with the necessary competences. Stronger institutional capacities to adapt to social changes must be developed, as the reports by Tomasevsky compellingly stated more than a decade ago (2006). This paper urges reflection and coincides with Calderwood et al.(2017, p. 2) when speaking of the results of the Eurostudent study of 2015, on that understanding the spill over effects of the study and work processes affecting resources' demand and allocation is crucial to increase the well-being of students who work, and in turn their contributions to society.

\section{References}

Calderwood C., Gabriel A. S. (2017). Thriving at school and succeeding at work? A demands-resources view of spillover processes in working students. Journal of Vocational Behaviour, 103, 1-13.

Council of Europe (1998): Recommendation R (98) 3 by the Committee of Ministers to member states on access to higher education

Communication from the Commission to the European Parliament, the Council, the European Economic and Social Committee and the Committee of the Regions on a renewed EU agenda for higher education. SWD (2017) 164 final. Retrieved from https://eurlex.europa.eu/legal-content/EN/TXT/?qid=1496304694958\&uri=COM:2017:247:FIN.

Darolia R. (2014). Working (and studying) day and night: Heterogeneous effects of working on the academic performance of full-time and part-time students. Economics of Education Review 38, 38-50.

Devlin M., James R. and Grigg G. (2008). Studying and Working: A national study of student finances and student engagement. Tertiary Education and Management, 14(2), 111-122.

Evan C., Gbadamosi G. and Richardson M. (2014). Flexibility, compromise and opportunity: Students' perceptions of balancing part-time work with a full-time business degree. The International Journal of Management Education 12(2), 80-90.

EUROSTUDENT 2016-2018. Social and Economic Conditions of Student Life in Europe Retrieved from http://www.eurostudent.eu/dowload_files/documents/EUROSTUDENT_VI_Synopsis_ of_Indicators.pdf. 
Gilchrist H.R. (2018) Higher Education as a Human right, 17Wash.U.Global Stud.L.Rev. 17, 645-676.

Hortósy R., Clark T. and Vickers D. (2018). Lower income students and the 'double deficit' of part-time work: undergraduate experiences of finance, studying and employability. Journal of Education and Work, 31(4), 353-365.

Hovdhaugen E. (2015). Working while studying: the impact of term-time employment on dropout rates. Journal of Education and Work. 28(6), 631-651.

International Convention on the Elimination of all Forms of Discrimination against Women. Retrieved from http://www.un.org/womenwatch/daw/cedaw/cedaw24/cedawcegy45.pdf.

Kalenkoski C.M., Pabilonia S.W. (2008). Parental Transfers, student Achievement, and the Labour Supply of College Students. BLS Working Papers. U.S. Department of Labour. U.S. Bureau of Labour Statistics, Office of Productivity and Technology. Working Paper 416.

Kõrgharidusprogramm 2017-2020. [High education programme 2017-2020]. Draft. Retrieved from: at: https://www.hm.ee/sites/default/files/8 korgharidusprogrammi_2017-2020_eelnou.pdf.

McCowan T. (2012). Is there a universal right to high education? British Journal of Educational Studies, 60(2), 111-128.

Pemberton J., Jewell S., Faggian A. and King Z. (2013). Higher education as a portfolio investment: students' choices about studying, term time employment, leisure, and loans. Oxford Economic Papers, 65(2), 268-292. DOI: 10.1093/oep/gps026.

PRAXIS. 2017. Eesti üliõpilaste eluolu 2016: rahvusvahelise üliõpilaste uuringu EUROSTUDENT VI Eesti analüüs. [PRAXIS. 2017 University student life in Estonia 2016: Estonian analysis of the EUROSTUDENT VI international university students survey].

Ramchand, B. and Dummugudem. (2014): "Inclusion Education as Solution to Barriers of CWSN and Answer for their Success.” International Journal of Humanities and Social Science Invention vol.3 no. 8.

Tomasevski, K. (2006) Human rights obligations in education: the 4-A scheme. Nijmegen:

Wolf Legal Publishers. Netherlands.

Töötasu alammäära kehtestamine. Vabariigi Valitsuse 13.12.2018 määrus nr 117. [Establishing the minimum salary. Government's decree 13.12.2018 nr 117].

UNESCO Convention Against Discrimination in Education. Retrieved from http://portal.unesco.org/en/ev.phpURL_ID=12949\&URL_DO=DO_TOPIC\&URL_SECTION=201.html .

United Nations International Covenant on Economic, Social and Cultural Rights. Retrieved from https://www.ohchr.org/en/professionalinterest/pages/cescr.aspx

Universal Declaration of Human Rights. Retrieved from https://www.ohchr.org/EN/UDHR/Pages/UDHRIndex.aspx.

Valk A. (2018). Vajaduspõhine õppetoetus ja selle mõju kõrgkooliõpingutele. Haridus- ja Teadusministeerium. 2018. [Valk A. (2018). Need-based study allowance and its impact to university education. Ministry of Science and Education. 2018] 